\title{
PECULIARITIES OF ESTABLISHMENT OF INTERNATIONAL RESPONSIBILITY OF THE STATE FOR THE BEHAVIOR OF EXECUTIVE AUTHORITIES
}

\section{Andreichenko S. S.}

\section{INTRODUCTION}

The primary and axiomatic rule, regarding the attribution of behavior for the purposes of State responsibility under international law - it is the principle that the conduct of a body of a State is regarded as an act of that State.

L. Oppenheim fairly pondered the question: "Since states are legal entities, whose internationally wrongful acts should be regarded as acts of the state and, therefore, as international offenses? To this question should be such an answer: firstly, all such actions, which committed by Heads of State or members of governments, acting as such, in that their actions are those of the State; secondly, all actions of officials or other persons, which is acting on orders or with the permission of governments. It is not an international offense an acts, which committed by Heads of State or members of government outside the scope their official duties, private entities which acting for themselves, not for the state"

T. Weiler, while giving a general description of the rule under consideration, noted that "this rule reflects the basic idea, that the state is an abstract concept. It can act only through individuals or legal entities, that is through the "body". In a sense the rule says nothing, apart from the observation, that when the state acts, it is the behavior of the state. There are two aspects to this rule that require further elaboration. The first being a public body; and the second notion, that any and all behavior of a public authority is assigned to the state"2.

The point of view, according to which actions or omissions of state bodies should be assigned to the state, was unanimously supported in the Governments' response to the Preparatory Committee of the 1930 Codification of International Law Conference. The Third Committee of the

1 Международное право: Мир. Перевод с английского. Т. 1 : Полут. 1 / Оппенгейм Л. ; под ред. : Крылов С. Б. (Предисл.) ; пер. : Лаутерпахт Г. М. : Иностр. лит., 1948. C. 336.

${ }^{2}$ Weiler T. International Investment Law and Arbitration : Leading Cases from the ICSID, NAFTA, Bilateral Treaties and Customary International Law . London : Cameron May, 2005. P. 29. 
Conference unanimously adopted, in the first reading Article 1, which provided for the international responsibility of a State in the event of any failure by its authorities to fulfill its international obligations ${ }^{3}$.

The rule, that according is attributes state behavior to its organs, which entails state responsibility in the event that such behavior is in breach of an international obligation of the state, reflects two main aspects. The first is the realization of the principle of unity of the state, from which it follows that the behavior of all state bodies, regardless of their functions and position in the state, belongs to the state. The second is that the international responsibility of the state may occur only, if the individual or legal entity acts as a public authority.

The principle, as a rule, restrains itself for the conduct of its persons acting, as clearly defined in international court decisions. The Permanent Chamber of International Justice further emphasized, that "States can act only with the help or through their agents or representatives". S. Olleson states: "Given the status of this rule, and of course its usual nature, there are a large number of cases, in which there is essentially no dispute, that the conduct of the authorities of the State is assigned to it; under these conditions, the question of attribution is unlikely to be avoided, and to some extent it is self-evident"

The International Law Commission in Article 4. from set of Articles 2001, defined: "The conduct of any body of a State shall be regarded as an act of that State under international law, whether that body exercises legislative, executive, judicial or any other functions, regardless of the position it occupies in the system of the State, and whether it is an authority of the central government or an administrative-territorial unit of the state". In their remarks on the draft articles, a number of governments have indicated, that the basis for attributing responsibility should be broad enough, that states cannot avoid liability, based on the formal definition of their bodies 5 .

Therefore, it is extremely important to correctly determine the status of bodies, whose actions are regarded as state behavior. The United Nations

${ }^{3}$ Commentaries to the draft articles on Responsibility of States for internationally wrongful acts adopted by the International Law Commission at its fifty-third session (2001). Report of the Commission to the General Assembly on the work of its fifty-third session / Yearbook of the International Law Commission. 2001. Vol. II, Part Two. P. 40.

${ }^{4}$ Olleson S. The impact of the ILC's articles on responsibility of states for internationally wrongful acts. London, British Institute of International and Comparative Law, 2009. P. 20.

${ }^{5}$ Report of the International Law Commission on the work of its fiftieth session, 20 April 12 June and 27 July - 14 August 1998. Official Records of the General Assembly. Fifty-third session. Supplement № 10. UN Doc. A/53/10 // Extract from the Yearbook of the International Law Commission. 1998. Vol. II (2). Para 363. P. 80. 
Commission on International Law has given serious consideration to this issue, considering it in the context of the problem of attribution to the state of conduct carried out by persons and bodies having the status of state according to its legal system.

\section{Definition of the term "public authority" for the purposes of international responsibility}

The term "public authority" conceptually means an entity, that forms part of the state's infrastructure. A state body is understood to mean a individual or legal entity, which carry out state power and through which the state functions. Since states are free, to organize their internal structure in whatever way they see fit, states are free to determine the bodies through, which they act.

The principle, according from which, all actions of all organs of a state can give rise to its international responsibility is equally recognized in the European human rights system. European Court of Human Rights in De Cubber v. Belgium (1987) clearly stated, that the state was responsible for the totality of its organs ${ }^{6}$. At the same time, the Court considered it necessary in a number of cases to emphasize that, in principle, it should not indicate, which national authority to bear responsible for a particular breach, that it merely establish the international responsibility of the State as a whole ${ }^{7}$.

This rule was also confirmed in the recent decision of the European Court of Human Rights Čikanović v. Croatia (2015), which concerned a breach of the right to a fair trial as a result of the national court's rejection of the applicant's claim for payment of wage arrears. The Court, citing earlier cases (Döşsemealtı Belediyesi v. Turkey, № 50108/06, 23 March 2010; Danderyds Kommun v. Sweden, № 52559/99, 7 June 2001; Yavorivskaya v. Russia, № 34687/02, 21 July 2005), noted that from the Court's point of view, the hierarchy between the various organs of the State is irrelevant when considering the case. Municipalities are public-law entities, which carry out state power and, whose acts or omissions, despite their degree of autonomy with respect to central authorities, may entail State liability under the Convention ${ }^{8}$.

Indeed, it can now be considered universally recognized that on international plan, the state to appear as a single unit, and one or another

\footnotetext{
${ }^{6}$ Case of de Cubber v. Belgium (Article 50). ECHR. Judgment of 14 September 1987 // EHRR. Vol. 13. P. 422.

${ }^{7}$ Гусейнов Л. Г. Международная ответственность государств за нарушения прав человека : [монография]. К. : Ин-т государства и права НАН Украины, 2000. С. 77.

${ }^{8}$ Čikanović v. Croatia. Judgment of the European Court of Human Rights of 5 February 2015. Para. 53 URL: http://hudoc.echr.coe.int/sites/eng/pages/search.aspx?i=001-150786.
} 
place of the organ in the system of state mechanism is significant, only from the point of view of internal law. Current international practice, also does not provide examples of references from separate states, to avoid liability for the "principle of autonomy" of state bodies".

International law recognizes, that the composition of states is obviously changing internally, and therefore, the definition of a public authority must necessarily be flexible. Thus, the idea of a state body is reduced to the basic concept of a subject, which is part of the state apparatus, regardless of the function it performs and regardless of the level of government.

Among the factors, influencing the definition of a state body, as such can be called: classification of establishment as a state body in accordance with the legislation of the state, participation of the state in financing the activity of this establishment, performance of state establishment, consideration of the subject of appointment of a person to a position and his subordination, state-owned entities.

At the same time, a state's own definition of a state body cannot be an indicative criterion for establishing, that it is a state body, and the conception of a state body for attribution purposes is predetermined by the principles of international law alone, since it is inadmissible to evade international liability by reference to internal law, which recognizes or does not recognize a particular entity, as a public authority.

\section{Features of attribution to the state of behavior of executive bodies}

Most of the actions, that became a reason for responsibility, come out from the executive branch, which provides the most direct exercise of state power. According to statements LG Huseynov, "there is no doubt that human rights and freedoms are mainly violated - and this is clearly evidenced by the huge flow of individual (including interstate) complaints, coming to interstate human rights institutions - by various acts of executive structures of the state. The fact is that, it is the branch of state power that, based on its functional purpose in the mechanism of the state, most often applies legislation and, accordingly, carries out a variety of activities, daily encountering individuals".

The jurisprudence of the Strasbourg authorities clearly illustrates the situation, that a violation of human rights is to a large extent a consequence of not a law itself, but a specific measure or decision taken by a relevant body, or official to enforce this law. So, the European Commission and the European

\footnotetext{
${ }^{9}$ Мазов В. А. Ответственность в международном праве : проблемы кодификации и прогрессивного развития норм и принципов международно-правовой ответственности. М. : Юрид. лит., 1979. С. 48.
} 
Court of Human Rights have in different years, considered claims of administrative detention, government decrees for compulsory study of certain subjects in schools, permission for expropriation and prohibition of construction work, interception of postal and telephone communications, by post services on the basis of regulating this sphere of legislative provisions, etc.

It is especially meaningful, when considering the issue that related with attribution to the state of the conduct of executive bodies is the activities of foreign relations bodies, which are official representatives of the state in international relations and, due to the carried out of their own functions, may lead to violation of the international obligations of the state, which entails the onset of international responsibility of the state (e.g. violation of the laws and customs of the host country by diplomatic agents). Most often, the state to bear liability for the actions or omissions of its executive bodies: ministries and agencies, army and police units, border and special services, down to the lower level of the executive branch.

In international doctrine and practice, was discussed the question whether on the international responsibility of the state a provisions of any body, in the structure of the state apparatus. E. Borchard believed, that only the behavior of higher authorities can be assigned to the state. This point of view has become widespread in American international law literature (Ch. Fenwick), G. von Glahn, and is reflected in Article VII (b) of the Harvard Project in 1929.

Relying on the International Arbitration Practice of 1850-1914, E. Borchard assumed the responsibility of the state for the behavior of its lower ranking bodies, only when it was directly or indirectly endorsed by higher authorities, for example when they did not take the necessary precautionary measures, whether they refuse to punish the guilty, or not give the victim access to court at all ${ }^{11}$.

An explanation of this concept can be seen in the fact, that international law at that time, rarely reached lower levels of government, except in a cases of violation of the rights of foreigners. But for these cases was provided a special order. Its role in spreading the concept under consideration in the United States played also features of the American legal system, which, unlike, for example, from European continental legal systems, often involves relatively unlawful actions of government employees, and especially lower-level officials, the

${ }^{10}$ Гусейнов Л. Г. Международная ответственность государств за нарушения прав человека : [монография] / Л. Г. Гусейнов. К. : Ин-т государства и права НАН Украины, 2000. C. 90.

${ }^{11}$ Borchard E. The Diplomatic Protection of Citizens Abroad or, The law of international claims. New York: The Banks law publishing co., 1915. P. 185-189. URL: https://archive.org/ stream/diplomaticprotec00borcrich\#page/n3/mode/2up. 
possibility of personally blaming an individual - the body, rather than being accused of violating the administration of the state as such ${ }^{12}$.

It is interesting fact, that during the 1930 Hague Conference on the Codification of International Law, a proposal was contributed to establish, that in the event of acts or omissions of lower-level officials, the State would not be held internationally responsible, if it recognized the wrongful conduct of the guilty official and will be punish him. However, this proposal was rejected ${ }^{13}$.

International arbitration practice has enough consistently adhered to the theory, that the behavior of bodies and officials at any level is attributed to the state. Founded by Mexico, and the United States in 1923, the General Commission of the claims in consider the case Roper, was disagreed with Mexico's position of the claims in the case Roper, disagreed with Mexico's position, which argued that the state was not responsible for the actions of the police, since there is a rule of international law, according to which the state is not responsible for the behavior of the lower level bodies.

In 1927, the Commission with decision found Mexico responsible. It was noted that "a clearly-established general principle requires, that each and every time when the state fails to fulfill its obligations, adopted within under international law in connection with the conduct, that deserves punishment one of the citizens (who are in her service), regardless of the position of the latter or his rank within internal law, it's bear liability for the wrongful acts of its officials" $" 14$.

The Panama Government, referring to the fact, that police agents are not normally regarded, as "power of the state," also sought to avoid liability for the wrongful conduct of lower-ranking officials, before the Panama-US General Commission on Claims in the case of Cecelia Dexter Baldwin, Administratrix of the Estate of Harry D. Baldwin, and Others (United States) v. Panama (1933). However, the Commission found Panama responsible in the decision on a case ${ }^{15}$.

The issue about a position administrative organ in apparatus of the state was violated in Ireland v. The United Kingdom (1978). In the present case, the Government of Ireland appealed to the European Commission on Human

12 Third Report on State responsibility, by Mr. Roberto Ago, Special Rapporteur, the internationally wrongful act of the State, source of international responsibility. A/CN.4/246 and Add. 1-3 // Yearbook of the International Law Commission. 1971. Vol. II, Part One. P. 62.

${ }_{13}$ Курис П. М. Международные правонарушения и ответственность государства. Вильнюс : Минтис, 1973. С. 173.

14 Лукашук И. И. Право международной ответственности. М. : Волтерс Клувер, 2004. C. 113 .

${ }^{15}$ Cecelia Dexter Baldwin, Administratrix of the Estate of Harry D. Baldwin, and Others (United States) v. Panama (1933) // Reports of International Arbitral Awards. Vol. VI. P. 328. 
Rights, complaining about the UK's violation of various articles of the Convention in Northern Ireland, in particular Art. 3, Art. 5, Art. 6, Art. 14, as well as Art. 15. The essence of the complaint was, that many persons deprived of their liberty, on the basis of extraordinary rules were subjected to torture, or other treatment contrary to Art. 3 of the Convention. One of the arguments of the defendant State, was that the higher administrative authorities not known about practices, used by the police and security forces of Northern Ireland.

In its judgment, the court upheld the principle, that the provision of an administrative authority was irrelevant for attributing unlawful conduct to a State and found, that the action and inaction of a competent authority with respect to its subordinates, could give rise to State liability within European Convention."The Convention not only obliges the higher authorities of the Contracting States, to respect from its side embodied in it the rights and freedoms ; as referred to in Article 14 (Article 14) and in the English text of Article 1 (Article 1) ("shall secure"), the Convention also provides that in order to ensure the exercise of these rights and freedoms, these authorities must prevent or eliminate any breach at lower levels"16.

In the case of Guillermo Ignacio Dermit Barbato and Hugo Haroldo Dermit Barbato v. Uruguay $(1981)^{17}$, considered by the United Nations Human Rights Committee, stated that the victim of the abuse had died, as a result of acts of in humane treatment and torture during its detention. However, the defendant State, denied this and stated that the victim had committed suicide. In its decision, the Committee found that, in all circumstances, the power of defendant State's authority to bear liability, either for action or omission, for failing to take adequate measures, to protect the life of the victim, as required by Article 6 (1) of the Covenant.

Another confirmation of the thesis, that the state attributes the behavior of lower-level executive bodies is the case of McCann and Others v. United Kingdom (1995). In this case from Intelligence data, the British and Gibraltar authorities have concluded, that a group of the Irish Republican Army would commit a terrorist act by laying a bomb with a remote control in a car.

The Operation management was assigned to the commander of the Special Airborne Service (SAS). Under the process detention, thinking that McCann and Farrell, and later Savage, were trying to use a remote control

\footnotetext{
${ }^{16}$ Ireland v. the United Kingdom. Judgment of European Court of Human Rights of 18 January 1978 // EHRR. Vol. 2. Para. 239.

${ }^{17}$ Guillermo Ignacio Dermit Barbato and Hugo Haroldo Dermit Barbato v. Uruguay. Communication № 84/1981. UN Doc. A/38/40 // Yearbook of the Human Rights Committee. 1983-1984. Vol. I. P. 419.
} 
mechanism to detonate a bomb embedded in the car, SAS officers shot them all at close range. None of the three suspects were identified with any weapons or remote control. The inspection found that the car, previously parked by Savage, also had no explosive device or bomb.

In deciding on the conformity of the applied force of Art. 2 of the 1950 Convention, the European Court of Human Rights carefully examined not only the question of the strictness of the force, used by military personnel with aim to protect people from unlawful violence, but also whether the government planned and conducted an anti-terrorist operation, so as to minimize (as far as possible) the use of force that led to life deprivation. To sum up, the Court noted, that depriving three terrorists of their lives did not constitute the use of force absolutely necessary, to protect people from unlawful violence. Accordingly, the Court held that the United Kingdom had breached Art. 2 of the 1950 Convention ${ }^{18}$.

Due to the actions of officials and public authorities lower-level, there is sometimes the question of applying the rule of exhaustion of local remedies. Therefore, it should be emphasized, that this rule applies only to foreign individuals and legal entities, under the jurisdiction of the state. According to this rule, they must use all available local remedies, to protect their rights, before applying to the State of nationality with requesting to grant diplomatic protection. If the actions of local authorities directly violate the international rights of the state, then the rule of exhaustion of local means does not apply.

In such a case, there is not arise a question of diplomatic protection. An example, give a case about a violation of the diplomatic immunity of a representative of a foreign country by a local authority. This provision was confirmed in 1956 by the Institute of International Law, which pointed to the existence of a principles of international law, which excludes the application of the rule on the exhaustion of local remedies in cases, where the act violates a person enjoying special international-legal protection ${ }^{19}$.

It should be agree with P.M. Kuris on the practical value of the rule of exhaustion of domestic remedies in the field of state liability for damage, caused to its territory by foreigners. It really reduces the number of international claims, from the side by foreign countries, whose citizens have been harmed, and in this sense plays a positive role in strengthening the principles of respect state sovereignty and non-interference. There is no

${ }^{18}$ McCann and Others v. United Kingdom. Judgment of the European Court of Human Rights of 27 September 1995. Paras. 192-214. URL: http://hudoc.echr.coe.int/sites/eng/ pages/search.aspx $? \mathrm{i}=001-57943$.

19 Лукашук И. И. Право международной ответственности. М. : Волтерс Клувер, 2004. C. 114. 
need, to bring to the international arena, what can be resolved with help, through the means provided by national law. This rule is fully in line with international law, which requires respect by foreigners of the laws of the host country ${ }^{20}$.

\section{Responsibility of the state for the behavior of persons from the composition of armed forces}

One of the actual aspects of attribution to the state of the behavior of executive bodies is the question of attribution actions of persons, from the composition of armed forces. J. Crawford writes, that "the most obvious manifestation of the executive power is the actions of the armed forces, which in the presence of armed conflict, are in all cases appropriated to the state, and entail international responsibility of the state" 21 .

In the past, there have been different approaches, to address this question. So, for example, J.-P. Queneudec noted, that before the beginning of the twentieth century, the arbitral awards distinguished, between acts of soldiers performed in the presence of an officer and independent acts of members of the staff. If in the first case, the state was held responsible, then in the second case, the actions of the members of the ordinary staff, were equated with the behavior of private individuals ${ }^{22}$.

For now, generally recognized is the principle of state responsibility, for all unlawful acts of the armed forces committed during wartime. Long existed principle of customary international law, established in Article 3 of the Hague Convention (IV) 1907 and confirmed in Article 91 of Additional Protocol I, is the rule, according to which the state is responsible for all acts committed by persons, who are in composition its armed forces. This principle, its the application of the general rule on the responsibility of the states for international illegal acts, by virtue of which state is responsible, for the actions of its bodies.

The Armed Forces are considered to be a state body, like any other executive, legislative or judicial power. The application of this general principle of responsibility in international humanitarian law has been reflected in four Geneva Conventions, which indicate the existence of State liability along with the requirement prosecution of persons for serious violations. The principle that, in addition to individual criminal liability,

${ }^{20}$ Курис П. М. Международные правонарушения и ответственность государства. Вильнюс : Минтис, 1973. С. 175.

${ }^{21}$ Crawford J. State Responsibility : The General Part. Cambridge : Cambridge University Press, 2013. P. 119.

${ }^{22}$ Queneudec J.-P. La Responsabilite Internacionale de l'Etat pour les Fauters Personnelles de ses agents. Paris : Librairie générale de droit et de jurisprudence, 1966. P. 184-185. 
there is a State responsibility is also confirmed in the Second Protocol to the Hague Convention for the Protection of Cultural Property (1999).

A number of military statutes contain provisions, stating that the state is responsible for violations of international humanitarian law. Some of these charters, clearly refer to actions taken by persons in composition the armed forces of the state, others in more general terms, speak of responsibility for serious violations or military crimes, without specifying to whom such actions should be carried out in order to be attribute to the State (for example, the military statutes of Argentina, the United Kingdom, Germany, Spain, Canada, Colombia, Nigeria, the Netherlands, New Zealand, the United States, Switzerland, Yugoslavia).

There is also a national existing law, that confirms this principal. In its decision in the Eichmann case of 1961, the Jerusalem District Court referred to the unlawful acts, committed by the accused in Germany as "acts on behalf of the state". Moreover, in the case of the payment of reparations in 1963, the Federal Supreme Court of Germany, referred to the "principle of public international law, according to which the State - party to the conflict is also responsible for actions which are not in accordance with public international law "and committed by its citizens in connection with conduct hostilities. In a case Distomo (2003), the same German court affirmed, that the responsibility of states for internationally wrongful acts, committed during hostilities "includes the responsibility of the state for the actions of all persons from the composition armed forces"23.

In J.T. case, which consider by the Hague (Netherlands) District Court in 1949 , talks about required the return of money, that had disappeared during the arrest a person by members of the Dutch Liberation Movement during World War II and, as it later emerged, was taken by the police. This case, still one confirmation of the principle, according to which states bear liability for violations of international humanitarian law, that committed by state bodies.

The official statements and practice, reflected in the reports also testify to the correctness of such a finding (e.g. statements by Austria, Argentina, United Kingdom, Israel, Indonesia, Iran, China, Mexico, Norway, Pakistan, Peru, Solomon Islands, USA, Turkey, and Yugoslavia), as well as the practice of Israel and Spain, reflected in the reports) ${ }^{24}$.

23 Henckaerts J.-M., Doswald-Beck L., Alvermann C. Customary International Humanitarian Law : Volume 1, Rules. / J.-M. Henckaerts, New York : Cambridge University Press. 2005. P. 531.

${ }^{24}$ Henckaerts J.-M., Doswald-Beck L., Alvermann C. Customary International Humanitarian Law : Volume 1, Rules. / J.-M. Henckaerts, New York : Cambridge University Press. 2005. P. 532. 
International judicial institutions also stand in the position of attributing to the state the behavior of its armed forces.

United Nations International Court of Justice in Jurisdictional Immunities of the State, Germany v. Italy (2012) stated: "If the crimes are committed by agents of the state, during an armed conflict, the state must take responsibility for the unlawful actions of its agents, and ensure compensation for the victims. Such compensation is usually made, through interstate mechanisms, or with help through special means established by the state responsible for the violation" 25 .

Another example of the State's responsibility, for the conduct of the armed forces is a case about armed action on the territory of the Congo. (Armed Activities on the Territory of the Congo) (Congo v. Uganda) (2005), which was considered by the United Nations International Court of Justice ${ }^{26}$. In this case the Court noted, that the behavior of the UPDF (Uganda People's Defense Force) is generally clearly linked to Uganda and is a behavior of a state bodies.

According to the established principle of international law, which is customary character, "the behavior of any body of a State should be regarded, as an act of that State." In the Court's view, in force a military status and the functions of Uganda soldiers in the DRC, their behavior is attributed to Uganda. Therefore, the allegation that these persons did not act as persons which carry out a state powers in specific circumstances is not evidence.

Furthermore, it does not matter to attribute their behavior to Uganda, whether the UPDF staff acted contrary to the instructions or exceeded their authority. In accordance with established rule of customary character, as this reflected in Article 3 of the Fourth Hague Convention on the Laws and Customs of the Land War of 1907, as well as in Article 91 of Protocol 1 to the Geneva Conventions of 1949, the party in armed conflict shall be responsible, for all actions of persons forming part of its armed forces ${ }^{27}$.

More earlier case Youmuns concerned a case, where Mexican troops introduced by the government to prevent an attack on three US citizens, not only dispersed the attacking crowd, but also take part in massive disturbances. On the grounds of that the soldiers were on duty, and under the

25 Jurisdictional Immunities of the State, Germany v. Italy. Judgment of the ICJ of 3 February 2012. Para. 17. URL: http://www.icj-cij.org/docket/index.php?p1=3\&p2=3\&case= $143 \& \mathrm{p} 3=4$.

26 Armed Activities on the Territory of the Congo (Congo v. Uganda). Judgment of 19 December 2005 // ICJ Reports. 2005. P. 168.

27 Armed Activities on the Territory of the Congo (Congo v. Uganda). Judgment of 19 December 2005 // ICJ Reports. 2005. Para. 214. 
command of a senior officer at the time, Mexico was found responsible for the deaths of Americans. If the troops wore civilian clothes, and participated in a riot, really as private citizens, Mexico probably wouldn't be held accountable ${ }^{28}$.

Indicated principle has been repeatedly has been confirmed by the European Commission on Human Rights in considering a number of interstate statements, against Turkey in connection with Cyprus events. "... the responsibility of Turkey is due, to the fact, that the Turkish armed forces have violated the rights and freedoms set out in the Convention by their actions and omissions ...."29. The International Criminal Tribunal as to former Yugoslavia, in its decision in a case A. Furundzhija's 1998 and in a decision of appeal case Tadich 1999, assumed that the state was responsible for the actions of its armed forces ${ }^{30}$.

In the case Hassan v. the United Kingdom (2014), to considering by European Court of Human Rights, the applicant claimed, that his brother had been arrested and detained by British troops in Iraq, and subsequently was found dead in unknown circumstances. The applicant complained, that the arrests and detentions were arbitrary, unlawful and carried out in the absence of procedural safeguards, and that the authorities of the United Kingdom had failed to investigate the circumstances of detention, ill-treatment and death ${ }^{31}$.

In this case, the Court found that, given the facts which was handle, there was no evidence to suggest, that Tarek Hasan to fail ill-treated while in the camp, that for the defendant State would arise a obligation, to conduct a official investigation. There is also no evidence, that the United Kingdom organs in any way, - directly or indirectly - to had responsibility, for the death of Tarek Hassan, which occurred about four months after he was released from Camp Bukka in a remote part of the country not controlled by forces The United Kingdom. In the absence of any evidence of the involvement of United States Government agents till the death, or even of any evidence that the death occurred in a UK controlled territory, none obligation to investigate under Article 2 arises.

${ }^{28}$ Crawford J. State Responsibility : The General Part. Cambridge : Cambridge University Press, 2013. P. 120.

${ }^{29}$ Гусейнов Л. Г. Международная ответственность государств за нарушения прав человека : [монография]. К. : Ин-т государства и права НАН Украины, 2000. С. 92.

${ }^{30}$ Henckaerts J.-M., Doswald-Beck L., Alvermann C. Customary International Humanitarian Law : Vol. 1, Rules. / J.-M. Henckaerts, New York : Cambridge University Press. 2005. P. 532.

${ }^{31}$ Hassan v. the United Kingdom. Judgment of the European Court of Human Rights of 16 September 2014. Para. 3 URL: http://hudoc.echr.coe.int/sites/eng/pages/search.aspx?i=001153724 . 
The Court stated that the complaints under Articles 2 and 3 of the Convention were manifestly ill-founded within the meaning of Article 35 $\S 3$ (a) of the Convention, and should be recognize inadmissible, according to Article $35 \S \S 3$ and 4 of the Convention ${ }^{32}$.

The state is also responsible for the omission of its organs, if they are obliged to take action, for example, commanders and other superiors are obliged to take measures, to prevent or punishment for its committed. This principle is reflected in Article 2 of the Article on States Responsibility, which states that an internationally unlawful act, may consist of "acts or omissions".

In the case of 1925, concerning the claims of Great Britain in Spanish Morocco, Judge Max Huber held that a State which had not conscientiously acted in its duty, to prevent unlawful acts or to punish members of armed groups for their perpetration was responsible ${ }^{33}$. In the case of the Essen Lynch Court, which considering by UK Military Court in Essen, German military guards were convicted for failing to protect prisoners of war Allied nations from the onslaught of the crowd. In the Velazquez Rodriguez case, the Inter-American Court of Human Rights ruled, that the state would be held responsible for the actions of armed groups, if it did not conduct a serious investigation into the actions, in a result which violated the individual's rights. A similar thought was expressed by the African Commission on Human Rights, and Nations in connection with the killings and ill-treatment of the armed conflict in Chad.

\section{CONCLUSIONS}

All actions and acts of executive bodies should be based on the law, not contradict it, aimed at the implementation of the law. The problem of attribution to the state of the behavior of the executive bodies, and of the general responsibility of the state for the activity of its executive bodies has always occupied a central place in the studies, related to the issues of international - legal responsibility. This was explained, not only by the fact, that in the system of named bodies includes a variety of bodies, and officials, ranging from the government, and ending with the ordinary police, but also the role played by the state responsibility for the damage, caused to the person and property of foreigners. Most often, violations of the rights of foreigners occurred, through the behavior of various levels of the executive branch.

\footnotetext{
${ }^{32}$ Hassan v. the United Kingdom. Judgment of the European Court of Human Rights of 16 September 2014. Para. 3 URL: http://hudoc.echr.coe.int/sites/eng/pages/search.aspx?i=001153724 .

33 Affaire des biens britanniques au Maroc espagnol (Espagne contre RoyaumeUni) (1925) // Reports of International Arbitral Awards. Vol. II. P. 642-646.
} 
Among the factors, influencing the definition of a state body as such can be called: classification of establishment as a state body, in accordance with the legislation of the state, participation of the state in financing the activity of this establishment, performance of state functions, consideration of the subject of appointment of a person to a position and his subordination, the existence of state control of the activity of establishment, state-owned entities.

A state's own determination of a state body cannot be an indicative criterion, in recognizing a particular entity, as a state for attribution purposes, since it is inadmissible to evade international liability by reference to internal law. The conception of the state body, for the purpose of attribution is determined by the principles of international law.

International doctrine and practice, testify to the existence in international law of a established principle, according to which the state is responsible for the actions, and omissions of all its executive bodies, regardless of their hierarchy. This principle is particularly sound in modern conditions in the context of attribution to the state of the illegal behavior of its armed forces.

\section{SUMMARY}

Among the factors influencing the definition of a state body as such can be called: classification of establishment as a state body in accordance with the legislation of the state, participation of the state in financing the activity of this establishment, performance of state functions, consideration of the subject of appointment of a person to a position and his subordination, the existence of state control of the activity of establishment, state-owned entities.

A state's own determination of a state body cannot be an indicative criterion in recognizing a particular entity as a state for attribution purposes, since it is inadmissible to evade international liability by reference to internal law. The conception of the state body for the purpose of attribution is determined by the principles of international law.

International doctrine and practice testify to the existence in international law of a established principle according to which the state is responsible for the actions and omissions of all its executive bodies, regardless of their hierarchy. This principle is particularly sound in modern conditions in the context of attribution to the state of the illegal behavior of its armed forces. 


\section{REFERENCES}

1. Affaire des biens britanniques au Maroc espagnol (Espagne contre RoyaumeUni) (1925) // Reports of International Arbitral Awards. Vol. II.

2. Armed Activities on the Territory of the Congo (Congo v. Uganda). Judgment of 19 December 2005 // ICJ Reports. 2005.

3. Borchard E. The Diplomatic Protection of Citizens Abroad or, The law of international claims. New York: The Banks law publishing co., 1915. URL: https://archive.org/stream/diplomaticprotec00borcrich\#page/n3/mode/ 2up.

4. Case of de Cubber v. Belgium (Article 50). ECHR. Judgment of 14 September 1987 // EHRR. Vol. 13.

5. Cecelia Dexter Baldwin, Administratrix of the Estate of Harry D. Baldwin, and Others (United States) v. Panama (1933) // Reports of International Arbitral Awards. Vol. VI.

6. Čikanović v. Croatia. Judgment of the European Court of Human Rights of 5 February 2015. URL: http://hudoc.echr.coe.int/sites/eng/ pages/search.aspx?i=001-150786.

7. Commentaries to the draft articles on Responsibility of States for internationally wrongful acts adopted by the International Law Commission at its fifty-third session (2001). Report of the Commission to the General Assembly on the work of its fifty-third session // Yearbook of the International Law Commission. 2001. Vol. II, Part Two.

8. Commission Nationale des Droits de l'Homme et des Libertes v. Chad, African Commission on Human and Peoples' Rights, Comm. No. 74/92 (1995). URL: http://www1.umn.edu/humanrts/africa/comcases/ 74-92.html.

9. Crawford J. State Responsibility : The General Part. Cambridge : Cambridge University Press, 2013.

10. Guillermo Ignacio Dermit Barbato and Hugo Haroldo Dermit Barbato v. Uruguay. Communication № 84/1981. UN Doc. A/38/40 // Yearbook of the Human Rights Committee. 1983-1984. Vol. I.

11. Hassan v. the United Kingdom. Judgment of the European Court of Human Rights of 16 September 2014. URL: http://hudoc.echr.coe.int/ sites/eng/pages/search.aspx?i=001-153724.

12. Henckaerts J.-M., Doswald-Beck L., Alvermann C. Customary International Humanitarian Law : Volume 1, Rules. / J.-M. Henckaerts,New York : Cambridge University Press. 2005.

13. Ireland v. the United Kingdom. Judgment of European Court of Human Rights of 18 January 1978 // EHRR. Vol. 2. 
14. Jurisdictional Immunities of the State, Germany v. Italy. Judgment of the ICJ of 3 February 2012. URL: http://www.icj-cij.org/docket/ index.php?p1 $=3 \& \mathrm{p} 2=3 \&$ case $=143 \& \mathrm{p} 3=4$.

15. McCann and Others v. United Kingdom. Judgment of the European Court of Human Rights of 27 September 1995. URL: http://hudoc.echr.coe.int/sites/eng/pages/search.aspx?i=001-57943.

16. Olleson S. The impact of the ILC's articles on responsibility of states for internationally wrongful acts. London, British Institute of International and Comparative Law, 2009.

17. Queneudec J.-P. La Responsabilite Internacionale de l'Etat pour les Fauters Personnelles de ses agents. Paris : Librairie générale de droit et de jurisprudence, 1966.

18. Report of the International Law Commission on the work of its fiftieth session, 20 April - 12 June and 27 July - 14 August 1998. Official Records of the General Assembly. Fifty-third session. Supplement № 10. UN Doc. A/53/10 // Extract from the Yearbook of the International Law Commission. 1998. Vol. II (2).

19. The Essen Lynching Case : Trial of Erich Ileyer and Six Others. British military court for the trial of war criminals, Essen. Judgment of 21-22 December 1945 // Law-Reports of Trials of War Criminals. The United Nations War Crimes Commission. Vol. I, London : HMSO, 1947. URL: http://www.eccc.gov.kh/sites/default/files/documents/courtdoc/00222779-0022 2784_0.pdf.

20. Third Report on State responsibility, by Mr. Roberto Ago, Special Rapporteur, the internationally wrongful act of the State, source of international responsibility. A/CN.4/246 and Add. 1-3 // Yearbook of the International Law Commission. 1971. Vol. II, Part One.

21. Velasquez Rodriguez v. Honduras (1988) // Inter-American Court of Human Right. Judgment of 29 July 1988. Ser. C. № 4 (1988).

22. Weiler T. International Investment Law and Arbitration : Leading Cases from the ICSID, NAFTA, Bilateral Treaties and Customary International Law. London : Cameron May, 2005.

23. Гусейнов Л. Г. Международная ответственность государств за нарушения прав человека : [монография]. К. : Ин-т государства и права НАН Украины, 2000.

24.Курис П. М. Международные правонарушения и ответственность государства. Вильнюс : Минтис, 1973.

25. Лукашук И. И. Право международной ответственности. М. : Волтерс Клувер, 2004. 
26. Мазов В. А. Ответственность в международном праве : проблемы кодификации и прогрессивного развития норм и принципов международно-правовой ответственности. М. : Юрид. лит., 1979.

27. Международное право : Мир. Перевод с английского. Т. 1 : Полут. 1 / Оппенгейм Л. ; под ред. : Крылов С. Б. (Предисл.) ; пер. : Лаутерпахт Г. М. : Иностр. лит., 1948.

\section{Information about the author:} Andreichenko S. S.,

Doctor of Sciences in Law, Associate Professor, Professor at the Department of International Law and Comparative Law, International Humanitarian University 33, Fontanska Road str., Odessa, 65009, Ukraine 